\title{
Article
}

\section{Corporate mediation: a proposition?}

\author{
Martin Brink*
}

\section{Introduction}

What is there to learn about managing conflict or negotiation that you do not already know? How can mediation techniques make a difference in achieving your personal goals and advance the objectives of your organisation even when there is no conflict? How can new skills benefit all management levels and change the role of the legal department?

This issue of the Corporate Mediation Fournal will address these and other questions. Is corporate mediation a prospect for the legal department and organisations as a mhole?

Trouble or key to growth?

Within and between organisations, disputes are a regular occurrence. Whether disputes are seen as trouble or as the key to growth is a matter of corporate culture. In a recent article in Harvard Business Reviem, Barsade and O'Neill point out the distinction between the cognitive culture and emotional culture of an organisation. When speaking of corporate culture the reference is typically to cognitive culture: the shared intellectual values, norms, artefacts, and assumptions that serve as a guide for the group to thrive. The emotional culture is made up of the shared affective values, norms, artefacts, and assumptions that govern the emotions that people have and express at work and that they are better off sup-

Martin Brink, PhD, is attorney at law, arbitrator and deputy judge at the The Hague Court of Appeals and an internationally certified mediator (MfN, IMI, CEDR Global Panel). This article is an extended version of a presentation given to the Dutch Legal Counsel Association on January 14, 2016. pressing. ${ }^{1}$ The positive pomer of criticism is the title of another publication in the same issue of HBR. ${ }^{2}$ These and other publications summarise the finding that the emotional culture relates to job satisfaction, creativity, engagement, loyalty, customer satisfaction, and quality of decision-making as well as absenteeism, burn-out rate and customer complaints. This emphasises the relevance of managing the emotional culture within an organisation.

It has been a never failing analysis during my 40 years of experience as a practicing attorney at law that the top of the pyramid determines the culture in an organisation. This applies to any kind of organisation, whether it is the leadership of a country, of a multinational company, a government agency, a single department or even the smallest of business units. It is the top of any such organisational group that sets the tone when it comes to what characterises the emotional culture. A trustworthy, transparent leadership, willing to self-reflect and sufficiently confident to allow or even invite contradiction, will create a psychologically safe environment in which people will feel recognised and be motivated. It is this kind of environment that will free energy to improve products or services rather than keeping energy hostage as a result of open or hidden controversies. When asked as a mediator to help a company in Switzerland address a formal complaint from an account manager against his direct line manager, head of department, and a vice president, my immediate inclination was to think about

1. Barsade S. \& O'Neill O.A. (2016, January-February). Manage Your Emotional Culture. Harvard Business Review, 2016, 58-67. See also Detert J.R. \& Burris E.R. (2016, January-February). Can Your Employees Really Speak Freely? Despite their best intentions, managers tend to shut people down. Harvard Business Review, 81-88. They point at the 'fear factor', that can easily and unintentionally exist, and the 'futility factor'. In many organisations they studied, the main reason for withholding ideas and concerns was not fear, but the belief that managers would not do anything with them anyway.

2. Verganti R. (2016, January-February). The Innovative Power of Criticism. Harvard Business Review, 89-95 
the role of the vice president first. In that particular organisational unit, he was the top of the pyramid and apparently he had not been able or willing to get the situation ironed out. In my first interview with the vice president, he explained that when confronted with the dispute between the account manager and his line manager, the first one was so agitated that he had felt it best to ask him to take a walk together 'and have an ice cream' in the nearby town. He promised the account manager that he would talk to the line manager and would come back on the issue when things settled down. His father had taught him that it was not wise, he said, 'to go and stand on a railway track when a train was running at full speed'. That is why he had decided to let time pass so the account manager and the line manager could 'cool off'. The ice cream or the lapse of time did not make the agitation go away but only added to the frustration of the account manager, even to the point where he filed a formal complaint. The vice president avoided confrontation rather than try to stop the train and get together with the account manager and the line manager to sort things out.

In any situation where there is trouble, start by looking at the leadership of the relevant unit or organisation. The importance of a leader, who has the skills to allow difficulties to come out into the open and address them in a constructive manner without retaliation, cannot be overrated.

In my book Due Diligence, ${ }^{3}$ I have listed a number of elements that can be monitored to read the culture of an organisation: how is the hierarchy organised, what is the labour productivity, and what is the staff turnover rate? Other elements include the absenteeism rate, and the level of investment in training and education (skills training) in relation to the turnover of the organisation. How is decision-making organised (how often are meetings held and how effective are those meetings)? What is the leadership style, the extent of involvement with one another and the manner of communication? An important benchmark is the question how dispute mise an organisation is. This concerns the way in which disputes are managed and solved. The question then is to what extent is a harmonious and sustainable way of solving disputes an integrated part of the organisation's culture? One element in this is whether the legal department is an integrated part of the organisation with a broader understanding of the mission and goals. ${ }^{4}$

Managing the emotional culture requires reading the DNA of an organisation: 'Regularly taking the pulse and temperature of what goes on under the radar'. ${ }^{5}$ This is not easily done. It takes a structured approach to con-

3. Brink M. (2011). Due Diligence, Onderzoeks- en mededelingsverplichtingen volgens het Nederlands recht. 2nd. Ed., The Hague: Boom Juridische Uitgevers, p. 88.

4. See American Arbitration Association. (2006). Dispute-Wise Business Management - Improving Economic and Non-Economic Outcomes in Managing Business Conflicts. New York: American Arbitration Association.

5. Doyle A.W., Eurocontrol Agency Mediator \& Ethics Officer. Presentation at the Fourth National Corporate Mediation Conference in Amsterdam, the Netherlands on 24 May 2016. sciously consider the interactions between various elements within an organisation (human, social, technical, information, political, economic, and organisational) in light of the organisation's goals. Doyle recommended various measures to this end including: analyse and understand (potential) sources of conflict, empower people to become more conflict competent, constructively promote and influence ethical behaviour, support risk management and risk mitigation, and provide a general narrative that can bring insight to information. ${ }^{6}$

There is also much to be gained between organisations if there is a focus on learning, preserving relationships and solving disputes, rather than just on right or wrong. Time spent on designing, cultivating and maintaining an environment in which conflicts are opportunities for learning and growth may generate value not only within an organisation but also in relationships with other organisations. ${ }^{7}$ This is not to say that every dispute can or will always be resolved, but it does imply that even if that is not the case, lessons may be drawn as to how to agree to disagree. It makes all the difference if respectful communication makes both sides to an argument feel understood, even if the mutual positions cannot be combined. Failing to come to an agreement can also lead to growth in this way. A mutual appreciation of the mechanics that are at play in a dispute may help to retain mutual respect, even if there is permanent disagreement. ${ }^{8}$

Some of the mechanics that are at play in a dispute are addressed here before taking a look at the value that soft skills may add within and between organisations in the form of corporate mediation. The focus in this contribution after that will be on the role of the legal function because there may be more to gain in this respect than with the human resources function. The aspects discussed subsequently may already be more internalised in the heart of the human resources department. Also, the role of the human resources function will receive ample attention in a following issue of this journal.

6. Doyle A.W., Eurocontrol Agency Mediator \& Ethics Officer. Presentation at the Fourth National Corporate Mediation Conference in Amsterdam, the Netherlands on 24 May 2016.

7. Data gathered by corporate counsel who have adopted planned early dispute resolution according to Research Resolution Systems Institute showed that, in one organisation, per case savings averaged $\$ 61,000$ for employment issues and $\$ 350,000$ for commercial disputes. Another organisation estimated savings of $\$ 1,000,000$ to $\$ 6,500,00$ per year. See Shack J.E. (2016, April-June). Mediate Early to Improve Dispute Resolution. Corporate Disputes, 116. At the time of finalising this article in Brussels in June 2016, the author helped to solve an issue that had been in litigation since 2005. The parties in a dissolved joint venture had already spent over 1.5 million in legal fees between them over a claim of twelve million euros, excluding the spent on management issues, missed opportunities in their market and other setbacks of litigation. The case was settled in 8.5 hours. The mediator fees a little over 4,000 euros. This is just one example.

8. Mayer B. (2009). Staying with Conflict, A Strategic Approach to Ongoing Disputes. San Francisco: Jossey-Bass. 


\section{The psychology of conflict}

\section{Holistic management}

Conflicts may take a great deal of management attention and energy, and delay or frustrate projects, lead to missed opportunities and thus also serious financial loss. Managing prevention and solution of conflicts is not an issue of the human resources or legal department alone. Most conflicts have nothing to do with legal aspects or terms of employment. The skill to constructively manage relationships in an organisation is therefore an important asset for every manager at every level and throughout an organisation. Although most of us feel that we already know how to manage our relationships, we all encounter tensions or conflicts regardless. Below it is investigated how conflicts can be analysed and what may be an answer to dealing with conflict.

\section{How it works}

When two parties in a dispute are sincere, they are both right. Since there is a dispute, they are most probably each broadcasting on a different wavelength and not receiving what the other party is broadcasting. Picture a number painted on the floor and a disputant on either side of that drawing, the one maintaining that the figure on the floor is a six and the other that it is a nine. Who is right? In less obvious situations than this, observers are often equally sincere. If there is conflict, the observation and interpretation is sincere since it concerns our heartfelt truth as we see it. However, that perception is coloured by our very different experiences, ${ }^{9}$ priorities and beliefs. When we do not succeed in finding an agreement then, fuelled by our sense of justice, the counterpart to the differing views becomes an adversary rather than someone like us looking at the same issue from a different perspective. The saying 'perception is truth' expressed in a more nuanced version ought to read that 'perception is our truth as we see it'. The same goes for everyone involved in a dispute. Simply put, we can call each perspective a paradigm, a way of looking at things. ${ }^{10} \mathrm{~A}$ dispute can then be defined as two differing paradigms, be it that differing paradigms only qualify as a dispute when the paradigm of the one impinges on something the other wants. ${ }^{11}$ That one person finds modern art great and the other does not like it at all does not need to cause a problem. Wanting to buy a work of

9. Past experiences may consciously but also subconsciously influence our perception by associative memory ('priming'). Our actions and emotions can be primed by events of which we are not even consciously aware. See Kahneman D. (2011). Thinking Fast and Slow, London: Penguin Books, pp. 52-59. Context may also be a factor. Gilovich and Ross mention the example of encountering a stranger on an otherwise empty street at night. Is it someone to fear? You are much more likely to come to that conclusion if you have just come from seeing a horror film than if you have just seen a romantic comedy. Gilovich T. \& Ross L. (2016). The Wisest One in the Room, How to Harness Psychology's Most Powerful Insights. London: Oneworld Publications, p. 84.

10. Also: a set of assumptions, concepts, values, and practices that constitute a way of viewing reality.

11. Garby T. (2016). Agreed! Negotiation/mediation in the 21st century. Paris: International Chamber of Commerce Publishing S.A., p. 15 art in that situation from a joint budget may cause a problem.

We regularly encounter situations with others who hold different values and opinions than we do. While discussions about those differences are not always easy, they are mostly conducted at a rational level and we make some effort to understand the differences. However, when we are challenged about what we consider 'the facts', we tend to find it much harder to contain our patience. It is easy to feel that only unreasonable people will fail to see the light once the facts are laid out. Yet, in disagreements about the facts, too, it helps to realise that the counterpart is likely to experience similar feelings and convictions. He or she will be equally convinced that your facts are not the facts. No matter how thinly one slices something, there are always two sides to it. It already sounds more conciliatory to refer to both sets of facts as the facts 'as perceived' by each one involved in the disagreement.

If we have seriously tried our best to avoid and solve a conflict without success, the issue may have to be escalated to an adjudicator, preferably within the organisation. If that does not help litigation, may become unavoidable. As the saying goes, a knot that cannot be untied will have to be cut.

\section{Adjudication?}

A disagreement that could not be resolved amicably (e.g. by means of negotiation or mediation, see below) may lead to litigation. Research in the Netherlands shows that $95 \%$ of all disputes are settled amicably either before, during or after litigation. ${ }^{12}$ In the US and Cana$\mathrm{da}$ this figure is said to be even higher. ${ }^{13}$ Although these figures need to be nuanced, ${ }^{14}$ they do make clear that in the end only a very limited number of cases are resolved through a verdict or an award. The question therefore seems to be how much money parties to a dispute want to burn before they settle a case, since it can be assumed that the case will get settled sooner or later regardless. So why not settle a dispute straight away and not first burn a lot of money and spend management time and energy that might have been used to grow one's business? I know various examples of parties who, after a long haul, succeeded in winning in litigation or arbitra-

12. Ter Voert M.J. \& Klein Haarhuis C.M. (2015). Geschilbeslechtingsdelta 2014. The Hague: Boom Juridische Uitgevers, Wetenschappelijk Onderzoek- en Documentatiecentrum, Ministerie van Veiligheid en Justitie. In only $15 \%$ of all disputes litigation is started (of which $4 \%$ in court and in $11 \%$ conciliation and dispute boards).

13. MacFarlane J. (2008). The New Lawyer, How Settlement is Transforming the Practice of Law. Vancouver: UBC Press, p. ix.

14. Often the relevant figures are derived by looking at how many disputes end up being adjudicated in court. It is, however, not entirely correct to assert, for example, that if only $2 \%$ of the cases are tried then $98 \%$ are settled. The figures include situations where plaintiffs did not pursue their case because of lack of means, out of frustration of for other reasons, for example. See among others Galanter M. (2004). The Vanishing Trial: An Examination of Trials and Related Matters in Federal and State Courts. Journal of Empirical Legal Studies, 1(3), 459-461, 507, and Barkai J. \& Kent E. (2014). Let's Stop Spreading Rumors About Settlement and Litigation: A Comparative Study of Settlement and Litigation in Hawaii Courts. Ohio State Journal on Dispute Resolution, 29, 85, 106-111. 
tion and afterwards wished they had never taken that road after evaluating the investment in cost and, above all, the negative energy it brought with it.

\section{Fatal shores?}

What is more, the outcome of litigation cannot be predicted. This may be different when it concerns statutes of limitation or simple rules of civil procedure law, but even then the outcome is not always as expected. In most other cases, it has not without reason been said that 'in court like at sea one is at the mercy of the gods'. One becomes separated from ownership of the outcome. Research has disclosed that even with the help of outside counsel, the outcome of arbitration or litigation could not be predicted with any degree of certainty. A study that quantitatively evaluated the incidence and magnitude of errors made by attorneys and their clients in unsuccessful settlement negotiations revealed startling findings. ${ }^{15}$ In the vast majority of cases the estimation of the outcome of arbitration or litigation was wrong. A large number of contested litigation cases were analysed in which the plaintiffs and defendants conducted settlement negotiations, decided to reject the other party's settlement proposal and proceeded to arbitration or court. The parties' settlement positions were compared to the ultimate award or verdict, revealing a very high incidence of decision-making error by both plaintiffs and defendants. Plaintiffs erroneously concluded that adjudication was the superior option in $61.2 \%$ of the cases, while defendants did so in $24.3 \%$ of the cases.

The grand total of errors in terms of decisions to abandon the settlement negotiation and to proceed to arbitration or litigation was therefore $85.5 \%$. The award or verdict rendered the same or a better result than had been available in the settlement negotiations in only $14.5 \%$ of the cases evaluated. An interesting outcome was that this percentage went up from 14.5 to $21.1 \%$ in those cases where a party was represented by an attorney who was also an experienced mediator. One of the reasons for the difficulty of predicting the outcome of litigation is that, depending on the adjudicator's perception of the issue at stake, the adjudicator can put reason into whichever solution he or she finds reasonable. Most of the times, there are rules or there is jurisprudence which applies to a case to be adjudicated, but then the application of those rules or that jurisprudence will depend on the interpretation of facts and circumstances of the case, and of the appreciation thereof by the adjudicator. Selecting the arguments to bring things together is an act of humans and not a mathematical process. So why not avoid such a tombola and settle disputes autonomously, even before it ever becomes subjected to adjudication?

\section{Natural reaction}

Much of what stands in the way of early settlement concerns different paradigms and an absence of a skillset to

15. Kiser R.L., Asher M.A. \& McShane B.B. (2008). Let's Not Make a Deal: An Empirical Study of Decision Making in Unsuccessful Settlement Negotiations. Journal of Empirical Legal Studies, 5(3), 551-591. bridge the differences. Also, we do not like to be wrong or even risk losing. These sentiments can be traced back to the basic evolutionary fear of being expelled from the tribe and having to spend the rest of one's life in solitude. This often meant a certain death. Since these sentiments are universal and natural, they exist on both sides of the divide. Until the realisation occurs on both sides of the divide that most times dealing with a dispute in the traditional manner is counterproductive to one's own interests, money and energy will be burnt before a settlement will be accepted. We cannot help trying to convince the other party to a conflict to see things through our eyes. If that fails even in settlement negotiations, we try to force our view upon the other with the help of litigation. The problem with litigation is that it is costly, lengthy and has an uncertain outcome. The saying 'The judicial system is something one goes into as a pig and comes out of as a sausage' is a testimony of litigants with experience.

Academic research and theory are robust on how cognitive bias - our own subjective interpretation of reality contributes to decision error. ${ }^{16}$ We pay a price for assuming that our own assessments are better than those of other people with similar information and expertise. ${ }^{17}$ Psychologists tell us that we ought to wary of our own judgement. We are more prone to look for evidence that will support our own ideas than for signs that we are wrong. We tend to apply 'a positive test strategy', i.e. to search for confirmatory information. This inclination comes naturally because it seems to follow directly from an unassailable proposition: if we think something is true, there must be evidence for it. So we look for that evidence. Supportive information will almost always be at the forefront and centre of our attention; contradictory information will often get lost in the scuffle. ${ }^{18} \mathrm{We}$ have to consciously put extra effort into surveying the evidence both for and against. An old lawyer's joke is about a client who sent a file to his attorney asking whether the case would stand any chance of victory in court. After studying the file the attorney was happy to report that there certainly was a fair chance of winning the case, whereupon to his surprise the client did not instruct him to commence a case, but to return the file to the client. When asked why the client did not want to pursue the case in court, the client told him that he sent him the file of his opponent in the case.

Another reason that could stand in the way of early settlement may be that an argument might have a legal aspect to it and so advice is sought from a legal expert. More often than not the issue then becomes entangled in legal argumentation, which may complicate matters more than simplifying them. The law is a separate lan-

16. Creo R.A. (2013). Right? Wrong? Who Cares? I Do Want to Be Right! Alternatives, 31(7), 106

17. Liberman V., Minson J.A., Bryan C.J. \& Ross L. (2012). Naïve realism and capturing the "wisdom of dyads". Journal of Experimental Social Psychology, 48(2), 507-512.

18. Gilovich T. \& Ross L. (2016). The Wisest One in the Room, How to Harness Psychology's Most Powerful Insights. London: Oneworld Publications, pp. 19 and 41. 
guage, a specific frame of reference, designed to provide law and order in society, and solutions to problems that could not be solved in terms of lay language or in direct communication between the parties involved in the argument.

The error rate in accurately predicting the outcome of arbitration or litigation $(85.5 \%)$ confirms the wisdom in settling cases through direct negotiations or with the help of mediation. Mediation can help to manage responses to communication failures and to help each party to a conflict to get a 360 -degree picture of the topic at hand.

\section{Mediation}

Mediation is a process whereby the parties agree to instruct a neutral person, who is independent from them, to assist them in trying to solve an issue that is dividing them. It is a voluntarily process, whereby they are encouraged to listen to one another confidentially without an obligation to continue if they do not want to continue. Unless there are other arrangements, they have to have the power to make binding agreements.

Mediation helps to bridge differences by helping parties to recognise that their take on 'reality' is just that - a paradigm and not an objective assessment of what 'just is' ${ }^{19}$ One might add that we are often mistaken about what just is, and equally about what is just. The objective of mediation is to facilitate a shift of paradigm. Negotiating peace in wartime with the killers of one's children is practically impossible until one realises that the other side is also negotiating with the killers of their children. The mediator has communication techniques that can help the parties to move from standpoints to shared interests. I like to think of mediation as a paradigm and a skillset. The paradigm is the realisation that both parties - if sincere - are both right and that thinking in terms of wrong or right is unproductive. The skillset consists of such things as encouraging the parties to actively listen to each other while suspending their own judgement, and confirming to each other an understanding of what has been said and of the intention behind what has been said (which is not the same as agreeing to it). It is important to verify whether there is a difference between intent and impact by verifying the intrinsic value of words, acts and impressions. This often already irons out whatever miscommunications may have taken place. Making a distinction between the role someone is performing on behalf of his or her organisation and the person in dealing with others is another example. The realisation that one can disagree with the beliefs or actions of another without having this amalgamate into dislike of the other as a person can make a real difference.

The idea of mediation is to get a different take on conflicting positions and disputes from what we may be accustomed to. I am not recommending giving way to everybody with a different standpoint or to always give in to the claims others make. There is nothing wrong with taking a stand for one's interests, positions and values. It is worthwhile fighting for interests, positions and values. The suggestion I am making is to fight differently. As with the roads to Rome, there are more ways than one to achieve the things we value and believe in. Think of the comparison between an outright fistfight on the one hand and an exchange of fears, wishes and interests on the other. An interesting experiment in a group was to ask everyone to find a partner, to sit face to face with each other, take each other by the right hand - in the position of arm wrestling - to close one's eyes and see who in the group could make the hand of the other touch the table most times during the course of two minutes. Fisher and Shapiro mention this experiment in their wonderful book Beyond Reason. The goal was for individuals to get as many points for themselves as possible during the exercise. It was reiterated that it did not matter how many points their partner would get. For two minutes each pair struggled as everyone tried by physical strength to force the back of the other's hand down to the table. With a lot of effort and against the physical opposition of each partner, almost no one scored more than a point or two. There was one exception. One participant who remembered that the goal was to get as many points as he could for himself was wholly indifferent to how many points his partner got. He made the first move by allowing his partner to get a quick and easy point, then took a point for himself and gave his partner another point. In that way, each of them collected many points, whereas the other participants did not score more than a single point between them. None of the others succeeded to get more than three points. In the post-exercise review it was pointed out that in spite of the use of the word 'partner' ('find a partner, not a foe') and the note that it would not matter how many points their partner would get, virtually every participant had made the unconscious assumption that they and the one they were doing the exercise with were adversaries. That adversarial assumption dominated their thinking and prevented them from getting as many points as they could have. ${ }^{20}$

The objective of mediation is to move differing standpoints and opposites to combined interests. It aims to alter the thinking in terms of adversaries into terms of joint problem solving. Most of the time it is cheaper than litigation and leads to solutions sooner. The law has only one answer to multiple truths; mediation can help to safeguard relationships and since it allows for more solutions than just winning or losing, it may contribute to possibilities for rejuvenated cooperation and even windows for new business.

The message of this introduction is that it is old school to think within a legal framework only, or only in terms of right or wrong. 


\section{Contra-indications}

Mediation steps away from the notion that differing opinions and standpoints need to stand in the way of finding solutions. The purpose is to meet the interests of all the parties involved in an issue as much as possible. At the very least, mediation will often be the better alternative to escalation or adjudication. Not always. There are situations in which topics or parties are involved that preclude engaging in a mediation process. It has been said that 'all cases may be suitable for mediation but not all parties.' Yet, in the Harvard Negotiation Law Review in $1994^{21}$ an inventory was made of contraindications, i.e. reasons why parties understandably would not consider mediation appropriate. Such reasons may be (1) a need to attain a goal that only a court or arbitrator can provide, such as a precedent valid beyond the immediate parties, public vindication or minimising or maximising the recovery; (2) in case of a matter of principle, ${ }^{22}$ such as the protection of intellectual property rights, for instance, to protect one's brand; (3) in the event of a wholly frivolous claim; or (4) the jackpot syndrome (an attempt to forge a settlement on the basis of nuisance value or damage to reputation, for instance, if it involves a class action). ${ }^{23}$

\section{Prévoir c'est mieux}

As a buffer between a discussion and litigation, it may be helpful to include in all commercial contracts a clause necessitating mediation before there will be recourse to adjudication. It prevents a defendant from becoming involved in sudden litigation, and will compel a plaintiff to first exhaust a different method of communication than the one that failed to resolve the issue earlier. It is better to have tried and failed than not to have tried to find an alternative solution to adjudication at all. Success rates in mediation are high. Failed mediation often still brings benefits. Remember that a mediation process will be confidential as agreed beforehand. The positions can be explained in a confidential environment in a less controversial and more vulnerable manner than in an adjudication or pre-adjudication phase. Issues of miscommunication may be sorted out. Emotions may be vented and so be removed as an obstacle to forming a clear judgement or of self-reflection. It may be helpful if lawyers in mediation explain the case for their clients in the presence of the other party who may come to appreciate that the interpretation of one's own lawyer is not the only way of looking at a situation. Solutions other than win or lose are possible and one can retain ownership over one's own solution, which may be more creative than what is on the menu in adjudication. These are

21. Sander F.E.A. \& Rozdeiczer L. (1994). Matching Cases and Dispute Resolution Procedures: Detailed Analysis Leading to a Mediation-Centered Approach. Harvard Negotiation Law Review, 10(1), 36-37.

22. A matter of principle is to be distinguished from a hard bargaining position or strategy.

23. An example would be a class action case just to force a settlement. It is, however, conceivable that a settlement reached with one plaintiff may also create a precedent that could be used against more substantial claims from others. just some of the advantages that may outweigh the cost of one or more mediation sessions.

Although strongly in favour of mediation, some organisations believe it is better not to include a mediation clause in contracts. A mediation clause will oblige a organisation to participate in mediation and it may sometimes be used against the organisation by parties who do not really have a substantial issue or claim, but simply want to engage the organisation in dialogue. It is also believed that a mediation clause in a contract raises expectations about a willingness to seek a compromise, which may or may not be the case. The absence of a mediation clause in a contract does not stop the organisation from proposing or accepting mediation as a means to solve problems. It leaves the decision open to considerations based on the circumstances of a relevant case, and allows freedom to decide oneself what would be the right moment to engage in mediation.

Mediation has much more to offer than merely 'in the shadow of the law' in a legal context before, during or after a court case. The techniques applied in mediation may be beneficial to everyday life both at home and at work. As a management tool, mediation techniques may deliver benefits throughout an entire organisation. Mediation techniques can be very useful, not only to prevent or resolve disputes but also to procure constructive commercial, customer and infrastructural relations.

\section{Corporate use}

The concept of mediation can be very beneficial within organisations and between organisations. Corporate mediation, as it is called, involves a component of negotiation to a larger extent than mediation in general. It is a mix of the psychological elements of communication and negotiation. We communicate and negotiate all day at work, most of the time without giving much specific thought to what we are doing and why. The science of communication and negotiation taught in mediation education offers powerful insights into the mechanics of interpersonal relations. It offers tools that can get things done that would not be achieved otherwise. A single remark about a dress may lead to full-fledged war between whole departments. ${ }^{24}$

The other message of this article is that it is a mistake to rely on a cognitive culture with rules and regulations alone. In the end what makes people tick are emotions. Soft skills help to address them and constructive confrontation may avoid issues being put off or being allowed to fester for a long time. The success of an organisation depends on the quality of cooperation between people, ${ }^{25}$ psychological safety and therefore good leadership. An organisation is well advised not to leave managing culture to the human resources department alone, but to see to it that - like risk management

24. See, for example, Ellison S.S. (2007). Taking the War Out of Our Words, The Art of Powerful Non-Defensive Communication (3rd ed.). Deadwood: Wyatt-MacKenzie Publishing.

25. See e.g. Edmonson A.C. (2012). Teaming: How Organizations Learn, Innovate, and Compete in the Knowledge Economy. San Fransisco: Jossey-Bass. 
- the responsibility and care for an emotionally sound culture are also part of the personal performance plan of all line managers. When it comes to compliance with such values and standards, the legal department may also see a role for itself.

Below it will be investigated what some of the benefits of using mediation or deploying mediation skills within and between organisations may be. In the process, mediation and mediation skills will be looked at in relation to in-house legal counsel and to the organisation.

\section{The legal department}

In-house legal counsel

Why would in-house legal counsel take an interest in mediation and mediation skills? It is because the role of legal counsel - like that of other providers of legal services - is subject to dramatic change.

'The law does not exist for the purpose of keeping lawyers employed.' A line from Richard Susskind back in the days when there was still a question mark punctuating The End of Lamyers. ${ }^{26}$ It is fair to say that Susskind has gotten past the interrogative. In his latest book, The Future of the Professions, ${ }^{27}$ he and his son Daniel write, 'We foresee that, in the end, the traditional professions will be dismantled, leaving most (but not all) professionals to be replaced by less expert people and high-performing systems.' Lawyers do not warrant special protection from progress. It is naive to think that information technology is going to radically transform every information-intensive industry on the planet except the legal one. ${ }^{28}$ An increasing number of law firm leaders believe that a 'Watson'-type computer with artificial intelligence could replace first-year associates and paralegals in the next five to ten years. Watson is an IBM product described as a 'cognitive computing' system. ${ }^{29}$ The internet already provides answers to most legal questions. Law firms and others provide on-line boilerplate templates for an increasing range of agreements and other legal documentation with multiple-choice variations for individual clauses. Case law and sources for interpretation are becoming readily available. Legal

26. Susskind R. (2010). The End of Lawyers, Rethinking the Nature of Legal Services. Oxford: Oxford University Press.

27. Susskind R. \& Susskind D. (2015). The Future of the Professions, How technology will transform the work of human experts. Oxford: Oxford University Press.

28. Flaherty D.C. (2016, Mar 3). The End of Lawyers, Period. ABA Legal Rebels. Retrieved from www.abajournal.com/legalrebels/article/the end_of_lawyers_period/?utm_source=maestro\&utm_medium=email\& utm_campaign=weekly_email (consulted on April 12, 2016).

29. Cassens Weiss D. (2015, October 26). Will newbie associates be replaced by Watson? $35 \%$ of law firm leaders can envision it. $A B A$ Journal. Retrieved from www.abajournal.com/news/article/will_ associates_be_replaced_by_watson_computing_35_percent_of_law_ firm_lead/?utm_source=maestro\&utm_medium=email\&utm_campaign= tech_monthly (consulted on April 12, 2016). An Altman Weil, Inc. survey among managing partners and chairs of 320 law firms with 50 or more lawyers found that only $20 \%$ of law firm leaders in 2015 said that computers will never replace human practitioners as opposed to $46 \%$ believing so only four years earlier in 2011. counsel is no longer the sole proprietor of legal information. In-house legal departments will have to re-invent themselves.

\section{'The Department of No'?}

In-house legal departments will have to change from what traditionally may have been looked upon as 'the Department of No' into a source of added value. In the International Bar Association publication General Counsel in the 21st Century, ${ }^{30}$ a number of distinguished contributors proffer their opinion on strategy and leveraging legal resources in the new age. Chapters on topics such as managing the legal department, innovation and new competencies expected from tomorrow's legal counsel, data handling and managing corporate legal operations efficiently are all worth reading. Much attention is given to the contribution in-house legal counsel give to important topics on organizations' agendas today, like risk management and compliance. It is made clear that the modern legal counsel must also redefine him or herself as a risk manager in the broadest of terms, paying full attention to the need for compliance. Knowledge of business administration is needed as well as a solid understanding of information technology. Computer literacy has to be considered a basic skill these days. The emphasis in many of the contributions to General Counsel in the 21st Century is on technology and organisational aspects of the work of the in-house counsel, as is the case in other books on the subject like the books written by Susskind. These contributions paint a picture of a cognitive organisational model. Limited attention is given to soft skills like negotiation and mediation skills. The reason may be that features of in-house counsel, such as being close to their (internal) clients, knowing them, being responsive and creative plus having good sector knowledge, being proactive, understanding the market and being visible, are not considered unique selling points for outside counsel (lawyers in law firms). ${ }^{31}$ Similar considerations therefore are applied to the in-house legal professional. For lawyers in law firms as well as in-house legal counsel, however, having technical and organisational knowledge will become a bare necessity. It will be the soft skills, like negotiation and mediation skills, that will make the difference in future.

\section{It is not just technology}

Writings like Susskind's and those in General Counsel in the 21st Century do confirm the sense that times are changing. Legal counsellors are seeking responses to a call for change. Recourse against disruptive developments is sought in skills such as project management, process insight and lean process management, workflow knowledge and understanding the difference between

30. Vaagt C.H. \& Gross W.P. (Eds.). (2015). General Counsel in the 21st Century: Challenges and Opportunities. Woking: Globe Law and Business Limited.

31. Corveleyn F. \& Rackwitz F. (2015). The legal disruption dilemma: a case study on new service. In C.H. Vaagt \& W.P. Gross (Eds.), General Counsel in the 21st Century: Challenges and Opportunities. Woking: Globe Law and Business Limited, p. 177. 
digital innovation, virtualisation and automation. The unique selling point would be finding a specific way of combining people, know-how and technology. ${ }^{32}$ It is my belief that, as rational as the foregoing sounds, soft skills are equally if not more important. Smart tools will become available to make processes function and to retrieve intelligent data. Since these processes and data will be made available to everyone and everywhere, those cognitive skills will not provide a unique selling point. In-house counsel will increasingly be able to make a difference by acquiring soft skills such as in-depth knowledge of negotiation and mediation. The Dutch Law Society is trying to re-model its professional education programme so that new lawyers will become trusted advisors, ${ }^{33}$ referred to as $\mathrm{T}$-shaped lawyer. The vertical bar in the $\mathrm{T}$ represents legal knowledge and the horizontal bar represents general knowledge and soft skills. The managing partners of five large law firms in the Netherlands suggested that the new lawyer would want to possess, not only knowledge of the law, but also basic knowledge of sociology, the economy and academic skills like analytical abilities and debating. Surprisingly they do not mention psychology. This led to the commentary $^{34}$ that, in addition to profound knowledge of the law, an in-depth understanding of conflict management would be more relevant. The reasoning is that basic knowledge of sociology and economics, for instance, will not be as helpful in resolving disputes as knowledge of conflict management, which entails negotiation and mediation skills. Conflict management certainly is an important element of what many lawyers particularly outside counsel - do on a daily or regular basis, but there is more to their job than just that. The soft skills I am referring to - such as listening as if you are prong and confirming that you understand someone's point of viem, to name but two examples - can also be beneficial to commercial dealings within and between organisations. Having mediation skills can help build bridges to connect people across departments, and these skills, which can be learned, combined with legal and other contributions that in-house legal counsel can bring to bear, will create a new image. No longer the 'Department of No', the legal function may add another tool to its toolbox and so become even more than the partner in business to the business as it is at present. Lippe used the example of Dieselgate to question where the lawyers were when plans matured within Volkswagen to rig test results. Not that having soft skills would have prevented the occurrence, but he may have a point when he says that 'skilled lawyers can combine the roles of a trusted problem solver with independent judgment and integra- ted understanding, working with the people making risk-based decisions'. ${ }^{35}$

\section{The organisation as a whole}

\section{Multiple use}

Risk management, compliance and ethics are high on the agenda of organisations. More than ever before, the media and public authorities as well as all stakeholders involved with an organisation have come to expect transparency and accountability. To this end, many organisations have adopted mission statements along with codes of conduct and rules on ethical behaviour. These rules and codes express principles and intentions. The thoughts and values they contain constitute the values and standards according to which an organisation wants its members to function and live their professional lives. In a fully transparent world, most products and services can be obtained from multiple sources. This confirms the view that being close to one's clients, both external and internal, knowing them, being understanding, responsive and creative, listening as if you are wrong and behaving ethically do provide unique selling points. Translated into the word culture, these features may ultimately be at least equally as important as the quality of one's products or services. When the same or comparable products or services can be obtained from several sources, the way the customer experiences an organisation's culture and responsiveness may determine the customer's decision to buy a product or service from that particular organisation or elsewhere.

\section{Constructive confrontation}

Mission statements and codes of ethics, however, do not explain how to implement them. The frequent recommendation that they contain to address non-compliant behaviour or mistakes directly does not really give the full answer. Pointing out non-compliant behaviour or mistakes might jeopardise the relationship with those one wants to address. The result may be that - other than perhaps by using the anonymous complaint or whistle-blower line - the relevant statements and codes remain print on paper or text on the website. This may be different if education and training has been provided as to how to deal with issues of risk or non-compliance in a manageable manner. Some organisations, such as Intel Corp. in the United States, one of the largest semiconductor makers in the world, have introduced deliberate, specific policies to help employees to address issues of concern and solve disputes. At one point, all fulltime employees were trained in 'constructive confrontation', a hallmark of Intel's company culture. The creed being that 'the only thing worse than too much

33. Maister D.H., Green C.H. \& Halford H.A. (2001). The Trusted Advisor New York: Touchstone.

34. Maassen J. (2014, October 6). Advocaten van de toekomst, liever $\pi$ dan T-shaped? Advocatie. Retrieved from www.advocatie.nl/advocaten-van -de-toekomst-liever-pi-dan-t-shaped.

35. P. Lippe (2015, October 13). The New Normal, Where were the lawyers, Volkswagen? ABA Legal Rebels. Retrieved from www.abajournal. com/legalrebels/article/volkswagen_where_were_the_lawyers (consulted in June 2016) 
confrontation is no confrontation at all. ${ }^{36}$ According to the then CEO of Intel Corp. Andy Grove, 'Dealing with conflict lies at the heart of managing any business. An issue can be put off, it can be allowed to fester for a long time, it can be smoothed over or swept under some rug. But it is not going to disappear. Conflicts must be resolved if the organisation is to go forward.' 37 The lessons taught were largely an expression of modern mediation skills.

It may feel somewhat paradoxical to seek out and delve into disputes rather than to steer away from them. However, to constructively confront disputes within one's organisation is a way to advance one's business. Research by Edmonson ${ }^{38}$ and others has clearly shown that organisations thrive, or fail to thrive, based on how well small groups within those organisations work. ${ }^{39}$ She reiterates that teams and other dynamic groups do not learn naturally. She outlines the factors that prevent them from doing so, such as interpersonal fear, irrational beliefs about failure, groupthink, problematic power dynamics, and information hoarding. Her message is that it is essential that leaders are able to shape these factors by encouraging reflection, creating psychological safety, and overcoming defensive interpersonal dynamics that inhibit the sharing of ideas. This applies equally to individuals within organisations and to the combination of individuals that form a team. The relevant findings were confirmed by empirical research carried out within Google in 2015 ('Project Aristotle') to investigate what the key to a successful team would be. There was behaviour that seemed important, like making sure teams had clear goals and creating a culture of dependability. But Google's data indicated that psychological safety, more than anything else, was critical to making a team work: 'To be fully present at work, to feel "psychologically safe", we must know that we can be free enough, sometimes, to share the things that scare us without fear of recriminations. We must be able to talk about what is messy or sad, to have hard conversations with colleagues who are driving us crazy. We can't be focused just on efficiency. ${ }^{, 40}$

\section{Cultural awareness}

A psychologically safe working environment does not usually occur automatically. Like at Intel, Google and

36. Sutton R. (2007). The No Asshole Rule, Building a Civilised Workplace and Surviving One That Isn't. London: Piatkus, p. 71

37. Grove A.S. (1984). How to make confrontation work for you. Fortune, 110, 73-76.

38. Edmonson A.C. (2012). Teaming: How Organizations Learn, Innovate, and Compete in the Knowledge Economy. San Fransisco: Jossey-Bass.

39. This was recently confirmed by research carried out by E. van der Fluit in a PhD study entitled 'An ethnographic study amongst air pilots'. See Van der Fluit E. (2015). Professionals en 'the sweet spot of conflict'. Utrecht University.

40. http://bigstory.ap.org/article/8c60341cc1da47e084b8e17e62e83c98/ google-searches-itself-build-more-productive-teams (consulted in June 2016). other organisations, introducing special programmes ${ }^{41}$ is necessary for creating an environment that will constitute a cognitive as well as an emotional organisation. This can only be driven and warranted from the top of the organisation, and be managed using a conceptual approach rather than being just good intentions. Even though the direct return on investment of introducing conflict management systems is not easily expressed in monetary terms, the value of reputation, culture branding and brand awareness may be substantial. ${ }^{42}$ Highpotential individuals will include these features in their considerations when aspiring to a career. To reiterate, in a transparent world where most goods and services can be obtained from multiple sources, culture may well be one of the determining factors for an organisation's success, if it is not already. There is also the added benefit of good customer relations, job satisfaction, customer loyalty, management of risks and compliant behaviour. It is inevitable that mistakes will be made, but lessons should be learnt from them and they should be turned into opportunities instead of covering them up or playing them down. If conflict management skills are included in the job descriptions and profiles of all managers, it will help to prevent and solve workplace disputes and to manage risks, ensure compliance with rules and regulations, and enhance commercial success. Conflict management skills can be a bridge between all these areas that are critical to the success of organisations.

Organisations do not stand to benefit if conflict management is used as a response to incidental hiccups in the organisation. That is merely damage control and at best incidental measures are put in place to prevent similar events. Most large organisations have some sort of programme in place to deal with workplace issues. This alone, however, does not create the emotional culture that lays the foundation for a dispute-wise organisation while at the same time supporting the success of the organisation in all its aspects. Broadly speaking, an organisation is dispute wise when (i) its legal department is highly integrated into the general corporate planning process and has an understanding of the broader business issues facing the organisation and its branch of industry; and (ii) its senior management focuses on preserving relationships and settling disputes using alternative dispute resolution rather than litigation. ${ }^{43}$ Helping to create an emotional side to an organi-

41. There are several so-called stepped dispute resolution programmes for workplace conflicts, for instance, those of ALCOA, Johnson \& Johnson, CIGNA, Shell and others, as well for commercial relationships, for instance, British Columbia Hydro and the Boston Central Artery/Tunnel Project ('the Big Dig'). See Chapter 21 in Folberg J., Golann D., Stipanowich T.J. \& Kloppenburg L.A. (Eds.). (2010). Resolving Disputes, Theory, Practice, and Law. New York: Wolters Kluwer Law \& Business, p. 745 onwards. From my own experience I know that AKZO Nobel and British Tobacco use these arrangements in their commercial agreements.

42. Kirchhoff L. \& Hammes M. (2013). Konfliktmanagement als Instrument werteorientierter Unternehmensführung. Frankfurt: Europa-Universität Viadrina.

43. See inter alia American Arbitration Association. (2006). Dispute-Wise Business Management - Improving Economic and Non-Economic Outcomes in Managing Business Conflicts. New York: American Arbitration Association. 
sation's culture is what a conflict management system is designed to achieve, ${ }^{44}$ but the benefits of negotiation and mediation skills go far beyond conflict situations.

Much can be gained from the deployment of negotiation and mediation skills throughout the entire organisation to prevent or resolve disputes and to benefit from those skills in commercial, customer and infrastructural relations. In what I like to call 'culture counselling', the aim is to internalise soft skills within an entire organisation. A project of this nature has to start at the top of the organisation. The logo of the Corporate Mediation Association is a pyramid. This is to affirm that 'the top of the pyramid', i.e. the top of any organised unit, be it a small team or a large corporation, determines the culture. This makes it imperative that the top of an organisation understands and will have experienced the power of soft skills. A culture-counselling project has to be endorsed and supported by the top of the organisation over time. Education and training in negotiation and mediation skills must start at the top of the organisation and involve those most senior people who have to deal most with conflicts. ${ }^{45}$ Subsequently, a second tier of high-ranking members of the organisation must go through the drill, preferably those who are receptive to what is being offered. With luck, they can then become the evangelists who win over colleagues and other key managers so that they too join the programme. It is not the intention that everyone who undergoes the training becomes a mediator. Instead, the objective is to acquaint people in leadership positions with alternative ways of connecting to people and to ensure that they benefit from the psychological insights being handed to them. They will in their turn influence the people they are leading and with whom they have dealings within their organisation and in other organisations. One of my own clients, a large engineering firm, wanted its engineers to be more assertive. They were completely dedicated to implementing beautiful projects properly but found it difficult to be a match for their counterparts who were much more commercially driven. Going through a culture counselling project helped the entire organisation to become more commercially aware while remaining dedicated to their work and their clients without fear of addressing issues in an assertive manner, to protect the bottom line.

Mediation skills are useful for much more than preventing or solving problems. A sound knowledge of and experience with these skills benefit everyday life within and between organisations. This is the proposition that corporate mediation has to offer.

\section{Conclusion}

Mediation is not for the faint-hearted. The term 'soft skills' is misleading when it comes to creating an atmosphere within an organisation that is not ignoring the elephant in the room and that seeks to address the things that are not going well. Much can be contributed to a learning organisation and an organisation that is psychologically safe if the top of the organisation itself experiences what a difference soft skills can make. The internalisation of negotiation and mediation skills throughout an organisation can make the difference between organisations. It should not be the mission of the human resources department alone to be attentive to the value of mindfulness and empathy. Amalgamation of the legal and psychological aspects will create a new legal function, able to work side by side on both commercial and legal aspects of projects. A deliberate amalgamation of organisational skills and mediation techniques throughout the organisation and at all management levels may render much added value, and may ultimately determine the organisation's success or failure. 